DOI https://doi.org/10.18551/rjoas.2017-10.24

\title{
PUSH FACTOR ANALYSIS OF YOUNG FARMER COMMUNITY BASED ON AGRIBUSINESS IN MALANG REGENCY OF INDONESIA: A CASE STUDY IN CURUNGREJO, WONOSARI AND PLAOSAN VILLAGES
}

\author{
Arvianti Eri Yusnita, Gunawan Cakti Indra \\ University of Tribhuwana Tunggadewi, Malang, Indonesia \\ E-mail: cakti.irdh@gmail.com
}

\begin{abstract}
Youth collective life in the majority of Indonesian society will create a community, including a community of young farmers. Young farmers community need to be formed because the young generation is one of the main hopes for the creation of sustainable agriculture as well as through one of the efforts to increase agricultural businesses. The formed community is influenced by driving factors including government, family, capital and farming. This study aims to determine the push factors that influence the formation of a young farmer community, the driving factors which are the most dominant and determine the best model on the formation of young farmer communities in Malang. The method used quantitative descriptive, with multiple linear regression analysis. The sampling method used was stratified random sampling, the total sample of 55 young farmers. The results showed that the push factors that influence the formation of communities of young farmers, governments, families, and farming, as well as the most dominant factor is the government. Young farmer community formed due to the model of the region of farming like citrus farming that is supported by the full involvement of the government, in this case the government advisors who are able to carry out its functions and its role as agricultural advisors by transferingtechnology and increasingthe farmers' Knowledge, Skills and Attitude (MCC).
\end{abstract}

\section{KEY WORDS}

Push factor, community, young farmers.

Collective society is easier to achieve the desired goal, than working individually. Indonesia's population is accustomed to working in groups in the form of appropriate cultural and local conditions and circumstances exist. In addition, the group or the community functions as a place to learn together. The community can exchange experiences and knowledge. Since government institutions have limits in assisting all layers of society, this problem can be tackled by empowering communities to implement societal development with the expectation to achieve positive goals for other layers of society. (Czepiel et al., 2013). According to Kedi, S. (2008), who states that farmers' decision-making process communitybased action, can be used as entry pointfor technology dissemination efforts.

Many communities can be formed by society, especially a group or a community of young people. Most of the group of young people who are rarely found or may not even exist is a group of young farmers, According to BPS data Susenas Kor (2014), the number of youth in Indonesia is around 61.83 million or 24.53 percent from 252.04 million. This number is very crucial for the formation of youth groups. On the otherside they tend to spend a lot of time to get together, the level of curiosity to find friends, and loved a hobby or pleasure is still high, but the government's attention on the agricultural sector is very large (Ngangi, Charles. 2011). We can find there are more young farmers in villages than cities, perhaps the younger rarely take higher education, get married at young age and also because in their village have agricultural land so that it can directly work there as farmer, Muksin Amri, jahi Margono Slamet and Djoko Susanto (2009) says, the majority of rural young farmers areworking on small plots of land or even landless, very minimum level of communication with the agricultural advisor, and having a positive perception that their natural environment surrounding is basically can be utilized. 
Of course, many factors contributeto low interests among young generation towardsagriculture.Therefore, it isdifficultto find young farmers, according to Arvianti, et al., (2015) one of the most dominant factors affecting the interest of the young farmers towards agriculture transpormasi is income aspect. Ning F, et al., (2015), also said that farming is not regarded as a promising work and economically unstainable by youth. There is also low involvement of youth in sustainable agricultural activities. In addition, there is low parental socialization and peer cohesiveness. Meanwhile, According to Manuaba, et al., (2010) rural peasant youth can be categorized as marginal groups that still require special facilities to help improving its ability, because according to Nurmala, et al., (2012), the agricultural sector acts as a source of livelihood of the principal portion of the villagers.

Government programs through the Department of Agriculture or the AdvisingHall has been widely applied.For example the formation of farmers' groups and farmers women means the members of these farmer groups are all those who have a profession as a farmer without any classification from any aspect, meanwhile according Triman Tapi, H.M. Tahir Kasnawi, H.M. Dervish DPS, they states that the social construction of farmers in the formation of farmer groups, is strongly influenced by cultural values and local traditions, in addition, the formation of farmer groupsare regarded as serving the government's needs (stakeholders) instead ofthe farmers', thereforethe formation of a peasant youth group is possible because they have anti-establishment rebellious attitude, hard working, never give up and always optimistic.Even the potentials among theyouth is greater and the spirit of hard working is higher and they are certainly a driving factor and future generations to agriculture, for institutional or farmer groups tend to be positioned as mere instrument to implement project, not as an attempt for a more fundamental and thorough empowermentsince the farmers themselves also still lacks ofenthusiasm and participation. In order to be able to act as a participatory farmer groups, according to Ajzen, I. (1991) institutions should be designed as an effort to improve the ability of the farmer groups itself as for example by forming a group or community of young farmers to become self-sufficient in supporting the development of sustainable agriculture agribusiness area.

Indonesian Statistic Center (BPS) estimatedEast Java population to be $38,847,561$ with $11,874,351$ people of it belong to youth (aged between 15 years to 34 years old), Malang regency population to be $2,544,315$ and 779,250 people of it belong to youth of $15-34$ years age group (data BPS Regency, Malang, 2015), and seen from these numbers of youththere is a potential to develop agribusiness based young farmer community through government program that creates sustainable farming which expected to help development in Indonesian agricultural sector. However, what are the influencing factors that cause the absence of young farmer community formation? Therefore, a problem that can be explored in this study is "analyzing the push factor on young farmers' agri-based community and be able to create strategies and best models in shaping young peasant communities.

\section{METHODS OF RESEARCH}

The research was conducted in Kepanjen, Malang Regency in three villages, namely: Curungrejo, Wonosari, and Plaosan. The research location is determined purposively based on the consideration that the three villages in Kepanjen is the villages which have an active group of farmers that are under the guidance of the District Extension Centers Kepanjen and there are farmers who are still relatively young. This study is limited to young farmers who handle the citrus crop.

Data collection methods used in this research is direct observation (observation), interviews, questionnaires, documentation, and literature review. The population in this study were young members of farmer groups in three villages (Curungrejo, Wonosari, Plaosan) in Kepanjen with the age range from 17 to 40 years, the number of samples to be taken as many as 55 people by using proportionate stratified random sampling technique pegambilan samples that belong to the probability sampling is a sampling technique that can provide equal opportunities for every member of the population to become members of the sample 
and is used when the populationhave members or elements that are not homogeneous and stratified proportional ( Sugiyono, 2016).

With the following conditions:

In Curungrejo village there are three groups of farmers: Tani Muda, Maju Makmur, and Muda Jayawith the total number of peasant youth are 25 people. In Wonosari there are two groups: Jaya Muda Tani and Makmur Sejati with 20 young farmer members. In Plaosan village there are three groups of farmers: Jaya I, Jaya Makmur Tani, and Tani Santosa. The number of young farmers is 10 people. The total population of young farmers in three villages is $25+20+10=55$.

In orderfor each taken sample is representingeach population in the three villages, the formula is the total population of each village is divided by the total population of the three villages multiplied by the number of samples used (respondents).

Mathematically the formula can be written as following:

$$
\text { Sample }=\frac{\text { the total population of each village }}{\text { the total number of population in the three village }} X \text { number of respondents }
$$

Variable measurement $Y$ variable or a dependent variable and the dependent variable, in this study, the dependent variable is the formation of communities ( $Y=$ community building.)

$Y$, for the driving factors that influence the formation of a community of young farmers are given the approach to land ownership, capital, the number of young members of the farming community. Factors that drives the formation of communities is the government (X1), family (X2), capital (X3), farming (X4).

To perform the test of the hypothesis is done by using multiple linear regression model:

$$
Y=a+b 1+b 2 X 2+X 1 \ldots . X n+b n
$$

Where: $Y=$ Given an approach to land ownership, capital, and the number of young members of the farming community; $a=$ constant; $X 1$ = government; $X 2$ = family; X3 = capital; X4 = farming; b1, b2, b3, = coefficient of regression

\section{RESULTS AND DISCUSSION}

Respondents Characteristics. Respondents Characteristics used in determining the limits of information and knowledge that can be given to respondents to be analyzed by the researchers. The characteristics of the respondents shall include age, employment status, educational level and status of land ownership.

Age. All respondents who becomes the object of research are those who 17 to 40 years oldthat belong to farmer groups and who have become members of farmer groups. Age between 17 to 40 years old are categorizexd by researchers as a young age according to legislation and the the experts opinion on the definition of youth.

Job status. In the three villages used as research field, respondents have a profession as a farmer, explained from daily works, $80 \%$ of their incomes are from agriculture and from 55 respondents who had studied only 10 people with lease land ownership status, five people who are landless peasants, and

40 people own their own land. From 55 respondents,three people who have two professions; those who have bachelor degree level of education (civil servants and employees) will remain a member of farmer groups, because they are landless and work as farmers.

Level of education. From the diagram above we can conclude that from 55 respondents, there are 15 people who are junior highschool graduates(8\%). 20 (62\%)Junior High School (SMP) graduates, $17(26 \%)$ High School (SMA) graduates, andthree (4\%) 
Bachelor (S1).The majority of respondent farmers are farmers who have education only at the level of elementary school (SD).

Table 1 - Level of Education Respondents

\begin{tabular}{ccccc}
\hline Education Level & Frequency & Percent & Valid Percent & Cumulative Percent \\
\hline Elementary School & 15 & 8,0 & 8,0 & 8,0 \\
Junior High School & 20 & 62,0 & 62,0 & 68,0 \\
Senior High School & 17 & 26,0 & 26,0 & 24,0 \\
Bachelor (S1) & 3 & 4,0 & 4,0 & - \\
Total & 55 & 100,0 & 100,0 & 100,0 \\
\hline
\end{tabular}

Source: Data processed, 2017.

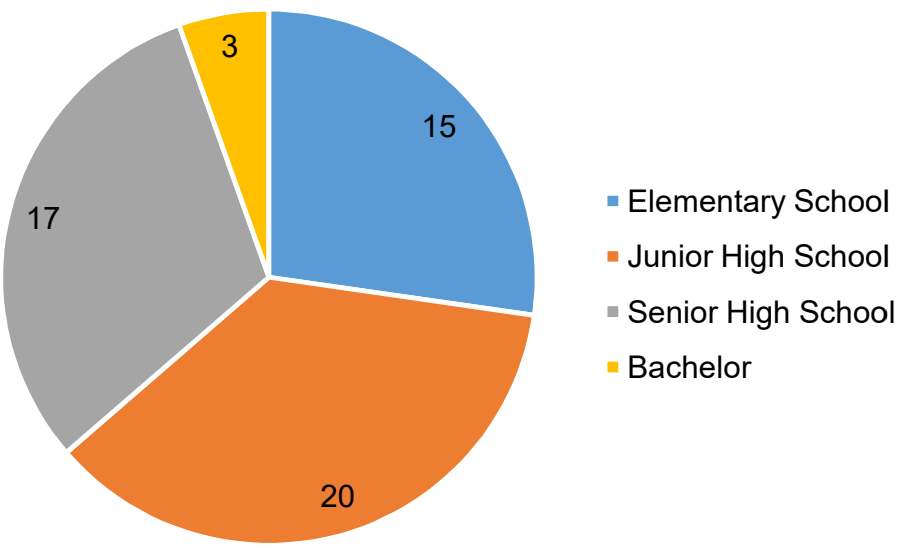

Diagram 1 - Level of education

Status of Land Ownership. From the diagram above we can conclude that as $55(92 \%)$ own their own land which in a sense is not leased landnor owned by parents. Three people $(6 \%)$ have land with lease status, and one person (2\%)is landless.

Table 2 - Land Status

\begin{tabular}{ccc}
\hline Land Status & Frequency & Percent \\
\hline Personal & 40 & 92,0 \\
Lease & 10 & 6,0 \\
Landless & 5 & 2,0 \\
\hline Total & 55 & 100,0 \\
\hline
\end{tabular}

Source: Data processed, 2017.

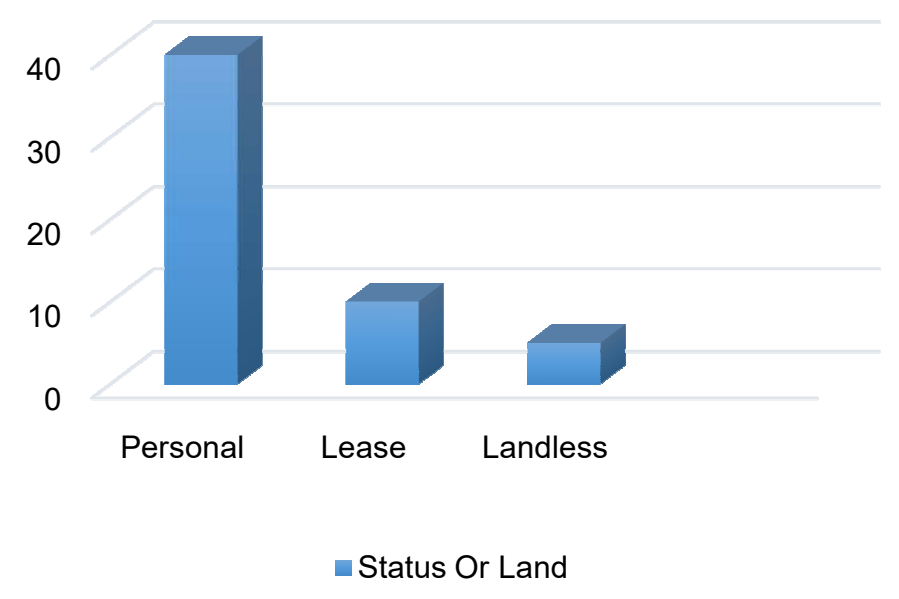

Diagram 2 - Status of Land Ownership 
Land area. From the diagram above we can conclude that from 55 respondents, 42 people $(84 \%)$ havezero to one hectare land area, nine people $(12 \%)$ have land area of over 1 hectare up to two hectares, three people $(2 \%)$ have more than 2 hectares of land up to 3 hectares and two people (2\%) have more than 3 hectares of land with up to 4 hectares and no respondents who have a land area of over 4 hectares.

Table 3 - Land area

\begin{tabular}{ccccc}
\hline Land Area & Frequency & Percent & Valid Percent & Cumulative Percent \\
\hline $0-1$ ha & 42 & 84,0 & 84,0 & 84,0 \\
$\leq 2$ ha & 9 & 12,0 & 12,0 & 96,0 \\
$\leq 3$ ha & 3 & 2,0 & 2,0 & 98,0 \\
$\leq 4$ ha & 2 & 2,0 & 2,0 & 100,0 \\
\hline Total & 55 & 100,0 & 100,0 & \\
\hline
\end{tabular}

Source: Data processed, 2017.

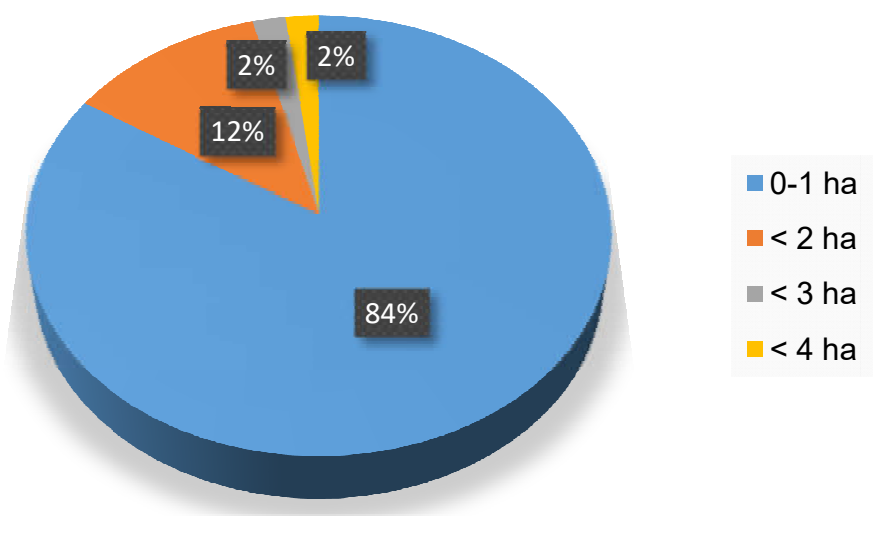

Diagram 3 - Land Area

Data Analysis Results with Multiple Linear Regression. After all regression assumptions are met, then the multiple linear regression analysis is conducted to obtain the effect of the independent variable on the dependent variable $X Y$. By using SPSS 21 software.

Research Hypothesis Testing:

Test $F$. Simultaneous testing is used to determine whether all of the variables used in the regression model have a significant effect on the variable $Y$ (forming a community of young farmers). All of these variables were tested simultaneously using $\mathrm{F}$ test used in testing the hypothesis that simultaneous or simultaneously is as follows:

$\mathrm{HO}$ : there is no real influence of independent variables on $\mathrm{Y}$

$\mathrm{H} 1$ : there is significant influence between independent variables on $\mathrm{Y}$

If the results are significant, then $\mathrm{HO}$ rejected and $\mathrm{H} 1$ will be accepted. But if the results are not significant, then $\mathrm{HO}$ and $\mathrm{H} 1$ rejected.

It can also be said to be as follows:

$\mathrm{HO}$ is rejected if $\mathrm{F}$ arithmetic $>\mathrm{F}$ table, or the value of Significance $<\alpha$.

$\mathrm{HO}$ if $\mathrm{F}$ arithmetic $<\mathrm{F}$ table, or the value of Significance $>\alpha$.

The Driving Factor:

Table 4 - Independent Variable Regression Coefficients Hypothesis Test towards Driving Factor Simultaneously

\begin{tabular}{lll}
\hline Hypothesis & Value & Decision \\
\hline $\mathrm{H} 0$ Independent variables no significant effect simultaneously on $\mathrm{Y}$ & $\mathrm{F}=27,315$ & Reject H0 \\
$\mathrm{H} 1$ independent variables simultaneously significant effect on $\mathrm{Y \alpha}=0: 05$ & sig $=0.000$ & \\
& $\mathrm{~F}_{\text {table }}=2,56$ \\
\hline
\end{tabular}

Source: Data processed, 2017. 
Based on the above table it can be seen that the values obtained Fhitung 27.315 and Ftable value of 2, 56 because of $F$ larger than $F$ table and has a significance value of 0.000 which is smaller than $\alpha(0: 05)$, so that $\mathrm{HO}$ is rejected. This means that simultaneously / concurrently, governments variable (X1), family (X2), capital (X3), and farming (X.4) there is real influence between independent variables to variable $Y$ (young peasant communities).

$T$ Test. Independent variable can be connoted as having signifficant influence on dependent variable. To test that relation, $T$ Test is used by comparing $t_{\text {count }}$ with $t_{\text {table. }}$.Regression model formation independent variable is stated as significantly influencing if $t_{\text {count }}>t_{\text {table }}$ or significant $<a=0,05$.

Partial regression model testing is used to determine whether each independent variable individually forming the regression model.

$\mathrm{HO}$ : there is no significant influence of each independent variable to variable $\mathrm{Y}$.

$\mathrm{H} 1$ : there is significant influence between each independent variable to variable $\mathrm{Y}$.

Decision-making:

$\mathrm{HO}$ is rejected if $|\mathrm{t}|>$ Ttabel, or value Significance $<\alpha$

$\mathrm{HO}$ if $|\mathrm{t}|<$ Ttable, or value Significance $>$

Table 5 - Hypothesis Independent Variable Regression Coefficients Against Partial Incentives

\begin{tabular}{cccccc}
\hline Variable & $\mathrm{B}$ & $\mathrm{t}_{\text {tabel }}$ & $\mathrm{t}$ & Sig & Keterangan \\
\hline (Constant) & 14,766 & 1,675 & 16,366 &, 000 & \\
Government &, 288 & 1,675 & 5,871 &, 000 & Significant \\
Family &,- 542 & 1,675 & $-8,144$ &, 000 & Significant \\
Capital &,- 086 & 1,675 & $-1,459$ &, 151 & Insignificant \\
Farming &, 188 & 1,675 & 3,491 &, 001 & ignificant \\
\hline
\end{tabular}

Linear Regression Coefficients Equations Factors Affecting Establishment of Young Farmers Community-Based Agribusiness Horticultural Crops can be written with a model of the following equation:

$$
Y=14.766+0.288 X 1-X 20.542-0.230+0.188 X 3 X 4
$$

If the value of $X_{1}$ rose 1 point then the $Y$ value increased by 0.288 assuming the other variables constant. If the value of $X_{2}$ down one unit then the $Y$ value fell by 0.542 assuming other variables constant. If the value $\mathrm{X} 3$ down one unit then the $\mathrm{Y}$ value fell by 0.230 assuming the other variables constant. If the value $X 4$ down one unit then the $Y$ value fell by 0.188 assuming the other variables constant.

1) The driving factors that influence the formation of communities in Kepanjen young farmers in three villages (Curungrejo, Wonosari, Plaosan).

- Government $\left(X_{1}\right)$ :

Government $\left(X_{1}\right)$ is the dominant variable, have t calculate equal to $5,871>$ ttable 1.675 with significantly 0,000 means that $\mathrm{H}_{0}$ is rejected and concluded that motivation variables significantly influence the variable $Y$ with the explanation that the more there is a push or government intervention against the farming community, then young farmers will increasingly want to become members of the farming community.

- Family $\left(\mathrm{X}_{2}\right)$ :

Family $\left(\mathrm{X}_{2}\right)$ have $\mathrm{t}_{\text {calculate }}$ equal to $-8.144<\mathrm{t}_{\text {table }} 1.675$ to 0.000 means significant $\mathrm{H}_{0}$ accepted thus concluded that the variables of the family did not significantly affect the variable $Y$ with the explanation that, the lesser encouragement from the family, the lesser willingness to become a member of the community as well.

- Farming $\left(\mathrm{X}_{4}\right)$ :

Farming $\left(X_{4}\right)$ have $t_{\text {calculate }}$ equal to $5,871>t_{\text {table }} 1.675$ with significantly 0,001 means that $\mathrm{H}_{0}$ is rejected and concluded that motivation variables significantly influence the variable $Y$ with an explanation if more farms owned, it is increasingly makemore young farmers be more interested to become members of farming community.

2) The driving factors that do not affect the formation of communities in Kepanjen young farmers in three villages (Curungrejo, Wonosari, Plaosan). 
- Capital $\left(\mathrm{X}_{3}\right)$ :

Capital has $t t_{\text {calculate }}$ equal to $-1.459<t_{\text {table }} 1.675$ to significant 0.151 means $\mathrm{H}_{0}$ accepted thus concluded that the variable capital does not significantly affect the variable $Y$ because young farmers acquire the majority of the capital not from a farming community, but from a financial institution outside the community and peasant communities that exist in Kepanjen which averagely do not have a cooperatives or money lender agencies.

A model that can create horticulture plants agribusiness based young farmer community in Kepanjen, Malang Regency, can be formed due to the existance of young farmers in a region or teritory with the same interests, trust, values, age, intelectual level, and profession as farmer, with the full involvement of the government will be able to encourage them to form a community, they also have the encouragement of family, as well as having their own farm. Young farmers also would like to build social relationships with their good fellows, createsdefense and security in the society, want to improve the economy of the family and be able to adapt to current circumstances, so the target indicators for these young farmers must have a good partner internally and externally in order to be able to attract the attention of young farmers so that the young farmer community is finally formed. In Malang Regency, particularly Curungrejo, Wonosari, and Plaosan horticultural farming region, Citrus plants are very attractive to young farmers, young farmers prefer to use the land for horticultural such as oranges compared to others. The reason of this preference lays in the production results. Single time land processing and plantation can generate multiple harvests until plants productive age is exhausted. This is different compared to rice which only has one harvest for one plantation.

Statistic Description of Respondents Answers. Statistic Description of Respondents Answers is a statistical tool used to analyze the picture data that will be called individually or in groups and give a systematic overview of data that is factual and accurate information on the facts as well as the relationship between the phenomena studied or investigated. In this research, descriptive analysis performed using SPSS version 21 statistics frequencies.

Statistics Description Frequency. To describe respondents through Frequency Statistic Description analysis on the educational level of 55 respondents, with 15 people among themas elementary school(8\%), 20 Junior High School graduates(62\%) 17 Senior High Schoolgraduates $(26 \%)$ and three Bachelors(4\%). This means that the majority of farmers have education level of secondary school (high school) with the status of land ownership by 40 respondents with a percentage of $92 \%$ own land that is in the sense of not land lease nor owned by parents. 10 people $(6 \%)$ have land with lease status and five people $(2 \%)$ are landless peasants, it means the majority of population ownstheir own land. For Curungrejo and Wonosari village land owned by farmers $(95 \%)$ is used for cit5rus plantation because it is a main commodity in both villages. While the majority of lands in Plaosan village are used for rice plantation or paddy fields. From both field utilization potentials in Curungrejo village, Wonosari with Plaosan vilage can also be compared through data from Kepanjen

From both the potential use of land in the village Curungrejo, Wonosari Plaosan village can be compared also with data owned by Technical Operating Unit-Developing Hall (UPT BP)in Kepanjen shows that the village land used for citrus plantationhave more young farmers than village land used for rice plantation.

\section{CONCLUSION AND RECOMMENDATIONS}

Based on the results of research and discussion that has been done related to research entitled "Analysis of Push Factor In Young Farmers Community-Based Agribusiness In Malang" it can be concluded that:

1. Push Factors that affect the formation of a community of young farmers, are the government, families, and farming;

2. The most dominant factor is the government;

3. A model that can create agribusiness based young farmers community in Kepanjen, Malang Regency, due to the existance of young farmers in a region or regions that have similar interests, beliefs, values, age, level of intelligence, as well as the similarity of the 
profession as a farmer therefore the full involvement of the government that will be able to encourage them to form a community, they also have the encouragement of family, as well as having his own farm. Young farmers also certainly want to build good social relationships, creating a defense and security in the society, want to improve the economy of the family and be able to adapt to the circumstances now, so the indicators to be achieved and owned by a young farmer must have partners of both internal and external order to be able to increase the economic progress of young farmers as well as to attract the attention of young farmers so that the young farmer community finally formed. In Malang Regency,especially Curungrejo, Wonosari, and Plaosan village farming area in the form of citrus plantation are also very attractive to young farmers, young farmers prefer to use the land for one of the fruit plantations such as citrus compared to others because they prefer citrus plantation due to it's production results. One land processing and plantation can generate multiple harvest until plants productivity age is exhausted. Farmers only need to focus on the treatment. It's different compared to rice fields that one planting only can generateone harvest.

Suggestions:

For the farmers, especially young farmers, increase intention and participation to join a farmer community.Because within the community we can share the knowledge and experience of both of the members, other government and private agencies, and also with the existence ofactive young farmers are farming in Indonesia can continue.

For the farming community, the community is not a place or organization for individual welfare or to enrichonly the leadership itself but the leadersshould be serving for the sake of all rank and file collective and common prosperity.

For the government and private institution, mainly engaged in agriculture, cooperate with farmers and farming community to actualize farmers aspiration, but do not make the farming community as a place to implement only a mere project.

\section{REFERENCES}

1. Ajzen, I. 1991. Theory of Planned Behavior. Organization Behavior and Human Decision Precess, 50: 179-211.[29 Januari 2016]

2. Arvianti, E, Y. Asnah dan Prasetyo A. 2015. Minat Pemuda Tani Terhadap Transformasi Sektor Pertanian Di Kabupaten Ponorogo. Jurnal. Buana Sains Vol 15 No 2: 181-188, 2015.PS. Agribisnis, Fak. Pertanian. Universitas Tribhuwana Tunggadewi. Malang.

3. Bungin, Burhan. (2006). Sosialisasi Komunikasi: Teori, Paradigma, dan Diskursus Teknologi Komunikasi di Masyarakat. Jakarta:Kencana

4. Czepiel et al. 2013. Competitor analysis. [Onine], http://pages.stern.nyu.edu/ jczepiel/Publications/CompetitorAnalysis.pdf

5. Dapertemen Pertanian. (2007). Pedoman Umum Peraturan Menteri Pertanian Tentang Program Pengembangan Usaha Agribisnis Perdesaan.

6. Diperoleh dari http://aciin.blogspot.co.id/2014/11/masyarakat-dan-komunitas.html.

7. Homan, M. S. 2004. Promoting Community Change; Making It Happen in The Real World. Thomson Brooks/Cole. Kanada

8. Manuaba, I, B Putera. (2010). Memahami Teori Konstruksi Sosial. Jurnal Masyarakat Kebudayaan Politik. Vol.21,NO.3:221-230. Surabaya: Fakultas IImu Budaya, Universitas Airlangga.

9. Muksin, Amri Jahi, Margono Slamet dan Djoko Susanto. 2009.Kualifikasi Pemuda Tani Perdesaan di Jawa Timur. Jurnal Penyuluhan. Vol. 5 No. 1. Maret 2009. Departemen Sains Komunikasi dan Pengembangan Masyarakat. Fakultas Ekologi Manusia, Institut Pertanian Bogor

10. Ngangi,Charles. (2011). Konstruksi Sosial Dalam Realitas Sosial. Journal ASE,Vol.7.No.2:1-4

11. Ningsih, Fitri danSofyan Sjaf. 2015. Faktor-Faktor Yang Menentukan Keterlibatan Pemuda Pedesaan Pada Kegiatan Pertanian Berkelanjutan. Jurnal Penyuluhan, Vol. 11 No. 1. Maret 2015. Departemen Sains Komunikasi danPengembangan Masyarakat, Fakultas Ekologi Manusia, Institut Pertanian Bogor. 
12. Sugiyono. 2016. Metodologi Penelitian kuantitatif, Kualitatif, dan R \& D. Cetakan ke-23. Alfabeta. Bandung.

13. Saputra, Aksin. 2014. Perbedaan Masyarakat Dan Komunitas.

14. Suradisastra, Kedi. 2008. Strategi Pemberdayaan Kelembagaan Petani. Jurnal. Forum Penelitian Agroekonomi. Vol.26. No. 2. Desember 2008.

15. Tapi, Triman, H.M. Tahir Kasnawi ,Dan H.M. Darwis DPS. Konstruksi Sosial Petani Dalam PembentukanKelompok Tani Di Kabupaten Manokwari. Sekolah Tinggi Penyuluhan Pertanian Manokwari,Papua Barat. Pasca Sarjana Sosiologi, Fakultas IImu Sosial Dan IImu Politik, Universitas Hasanuddin, Makasar. distributed under the terms and conditions of the Creative Commons Attribution (CC BY) license: http://creativecommons.org/licenses/by/4.0/ 